\title{
MORTALITY PREVENTION IN SEPTIC MICE WITH MULTIPLE ORGAN DYSFUNCTION SYNDROME: THE OPTIMAL DOSE OF INTRAPERITONEAL HEAT SHOCK PROTEIN 70
}

\author{
IGL SUKAMT0 ${ }^{*}$, BAMBANG PURWANTO ${ }^{2}$, AMBAR MUDIGDO $^{3}$, SUROTO $^{4}$, BHISMA MURTI $^{5}$, \\ IKA YULI AYUNINGRUM ${ }^{5}$
}

${ }^{1}$ Doctoral Program in Medicine, Universitas Sebelas Maret, Surakarta, Indonesia. ${ }^{2}$ Department of Internal Medicine, Dr. Moewardi/Faculty of Medicine, Universitas Sebelas Maret, Surakarta, Indonesia. ${ }^{3}$ Department of Anatomic Pathology, Dr. Moewardi/Faculty of Medicine, Universitas Sebelas Maret, Surakarta, Indonesia. ${ }^{4}$ Department of Neurology, Dr. Moewardi/Faculty of Medicine, Universitas Sebelas Maret, Surakarta, Indonesia. ${ }^{5}$ Masters Program in Public Health, Universitas Sebelas Maret, Surakarta, Indonesia. Email: igl.sukamto.span.dr@gmail.com.

Received: 06 June 2018, Revised and Accepted: 04 July 2018

ABSTRACT

Objective: Heat shock protein 70 (HSP70) reduces the expression of cytochrome C, B-cell lymphoma-associated X, and cysteine-aspartic acid protease 3 (Caspase 3), in apoptosis of multiple organ dysfunction syndrome (MODS), and thereby can prevent death. Previous researchers used $226 \mathrm{mg} / \mathrm{kgBW} /$ intraperitoneal (ip) of HSP70. This study aimed to determine the lowest effective dose of HSP70 to prevent death in sepsis mice model with MODS.

Methods: This was a randomized control trial conducted at Pusat Antar Universitas (PAU), Gadjah Mada University, Yogyakarta, Indonesia, from April 1, 2017 to April 21, 2017. The study subjects were Balb/c strain mice. The drug used to induce death was lipopolysaccharides (LPS). The drug used to prevent death in this study was Rat HSP70. A sample of 25 mice was randomized into five groups with each consisting of five mice: (1) Control group with $\mathrm{NaCl}$, (2) experimental group receiving LPS injection of $0.25 \mathrm{mg} / \mathrm{kgBW} / \mathrm{i} . \mathrm{p}$, (3) experimental group receiving the same dose of LPS injection with HSP70 injection of $100 \mu \mathrm{g} / \mathrm{kgBW} / \mathrm{ip}$, (4) experimental group receiving the same dose of LPS injection with HSP70 injection of $200 \mu \mathrm{g} / \mathrm{kgBW} / \mathrm{ip}$, and (5) experimental group receiving the same dose of LPS injection with HSP70 injection of $300 \mu \mathrm{g} / \mathrm{kgBW} / \mathrm{ip}$. Percentage of live mice between groups was compared by Chi-square test.

Results: 3 days after intervention, 13 (86.7\%) live mice in the experimental group with $\geq 100 \mu \mathrm{g} / \mathrm{kgBW} / \mathrm{i} . \mathrm{p}$ HSP70 were $>2$ (40\%) live mice in the experimental group with $<100 \mu \mathrm{g} / \mathrm{kgBW} / \mathrm{i} . \mathrm{p}$ HSP70, with $\mathrm{p}=0.038$. All mice receiving $\geq 200 \mu \mathrm{g} / \mathrm{kgBW} / \mathrm{ip} \mathrm{HSP70}$ in the experimental group were Alive 3 days after intervention.

Conclusion: The lowest effective dose of HSP70 to prevent death in sepsis mice model with MODS is $200 \mu \mathrm{g} / \mathrm{kgBW} / \mathrm{ip}$. All mice are alive 3 days after receiving $\geq 200 \mu \mathrm{g} / \mathrm{kgBW} / \mathrm{ip} \mathrm{HSP70}$.

Keywords: Lipopolysaccharide, Heat shock protein, Multiple organ dysfunction syndrome, Dose.

(c) 2018 The Authors. Published by Innovare Academic Sciences Pvt Ltd. This is an open access article under the CC BY license (http://creativecommons. org/licenses/by/4. 0/) DOI: http://dx.doi.org/10.22159/ajpcr.2018.v11i11.27773

\section{INTRODUCTION}

Sepsis is a serious and complex health problem that can immediately lead to some worse situations, such as multiple organ dysfunction syndrome (MODS), septic shock, hospitalizations, and death [1-3]. The MODS can be defined as the development of potentially reversible physiologic derangement involving two or more organ systems not involved in the disorder that resulted in ICU admission and arising in the wake of a potentially life-threatening physiologic insult [4]. In MODS, apoptosis occurs as a vital component of various processes including normal cell turnover, proper development and functioning of the immune system, hormone-dependent atrophy, embryonic development and chemicalinduced cell death [5-7]. The term "apoptosis," introduced by Kerr in 1972, refers to the morphological formation of apoptotic bodies in a cell [8].

There are two strategies that can be opted to address sepsis: (1) De-escalation and (2) heat shock protein (HSP). Antimicrobial deescalation has been defined as a mechanism whereby the provision of effective initial antibiotic treatment, particularly in cases of severe sepsis, is achieved while avoiding unnecessary antibiotic use that would promote the development of resistance. De-escalation or streamlining of empirical antimicrobial therapy on the basis of culture results and elimination of redundant combination therapy can more effectively target the causative pathogen, resulting in decreased antimicrobial exposure and substantial cost savings. Hence, de-escalation strategy can be used to treat patients with sepsis $[9,10]$. However, there are some challenges in implementing de-escalation. There is a natural propensity, particularly in severe sepsis, when the patient who has been very seriously ill is starting to get better, to stick with a treatment regimen that is working rather than change to an alternative agent [9].

HSPs are a group of such proteins that bind to such surfaces during assembly of large molecules and prevent the occurrence of incorrect union/interactions between parts/surfaces of the molecules [11]. In MODS, HSP 70 (HSP70) inhibits upstream and downstream mitochondria apoptosis by restricting cytochrome C (Cyt C), B-cell lymphoma (BCL)-associated X (BAX), and caspase 3 expressions, which eventually decreases mortality rate $[12,13]$

As previous studies have shown, such as Aschkenasy et al. (2011), that administration of exogenous HSP 70 with $266 \mu \mathrm{g} / \mathrm{kg}$ on septic mice model increased the number of BCL-2, which inhibited apoptosis [6]. Similarly, Choudhury et al. (2011) reported that the administration of exogenous of HSP70 inhibited apoptosis, by preventing the release of Cyt C complex, apoptotic protease-activating factor 1 (Apaf 1), procaspase 9 , and caspase 3 , respectively. Hence, caspase 3 is the immediate executor of apoptosis [12]. 
Another author injected exogenous HSP70 with $266 \mu \mathrm{g} / \mathrm{kg}$ dose $10 \mathrm{~min}$ before and after the administration of intravenous $2 \mathrm{mg} / \mathrm{kg}$ dose lipopolysaccharides (LPS) reduced mortality of mice and modified some homeostasis and hemodynamic parameters [14].

In contrast to the beneficial effect of HSP, some studies have shown the deleterious adverse effect of HSP. For example, Lee et al. had shown an important issue in the association between $H$. pylori infection and a contradictive role of HSP as a good worker for defense against $H$. pylori infection and HSPs as a bad offender contributing to the progression of H. pylori-associated gastric carcinogenesis in addition to aggravation of gastric inflammation [15]. Therefore, there is a need to investigate the lesser dose of HSP 70 than $266 \mu \mathrm{g} / \mathrm{kgBW}$ that is still effective to prevent death.

This study aimed to determine the lowest effective dose of HSP 70 to prevent death in sepsis mice model with MODS, which was previously injected by intraperitoneal $0.25 \mathrm{mg} / \mathrm{kgBW}$ LPS.

\section{METHODS}

This was a randomized control trial conducted at Pusat Antar Universitas (PAU), Gadjah Mada University, Yogyakarta, Indonesia, from April 1 to 21,2017 . The study subjects were Balb/c strain mice. The drug used to induce death was LPS from SIGMA L2880-10MG Lot \#025M4040V from Escherichia coli 055:B5 purified by phenol extraction. The drug used to prevent death in this study was Rat HSP70 Lot\#L16020515. A sample of 25 mice was randomized into five groups with each consisting of five mice:

- P0: Control group with $\mathrm{NaCl}$

- P1: Experimental group receiving LPS injection of $0.25 \mathrm{mg} / \mathrm{kgBW} / \mathrm{i} . \mathrm{p}$;

- P2: Experimental group receiving LPS injection of $0.25 \mathrm{mg} / \mathrm{kgBW} /$ intraperitoneal (ip) with HSP70 injection of $100 \mu \mathrm{g} / \mathrm{kgBW} / \mathrm{ip}$;

- P3: Experimental group receiving LPS injection of $0.25 \mathrm{mg} / \mathrm{kgBW} /$ ip with HSP70 injection of $200 \mu \mathrm{g} / \mathrm{kgBW} / \mathrm{ip}$;

- P4: Experimental group receiving LPS injection of $0.25 \mathrm{mg} / \mathrm{kgBW} /$ ip with HSP70 injection of $300 \mu \mathrm{g} / \mathrm{kgBW} / \mathrm{ip}$.

The percentage of live mice between groups was compared by Chisquare test.

The Research Ethics Clearance for this study was granted by the Research Ethics Committee, Dr. Moewardi Hospital, Surakarta, Indonesia, number: 377/IV/HREC/2017. The handling of animal (mice) subject in this study followed "Guide for the Care and Use of Laboratory Animals" by National Research Council of the National Academies. Researchers conducting surgical procedures at PAU Laboratory, Gadjah Mada University, Yogyakarta, Indonesia, already had appropriate training to ensure that good surgical technique was practiced, that is, asepsis, gentle tissue handling, minimal dissection of tissue, appropriate use of instruments, effective hemostasis, and correct use of suture materials and patterns.

\section{RESULTS}

A total number of 25 male /c mice were examined in this experiment with ages ranging from 6 to 8 weeks and body weight 26-33 g. By day 2 , all of the mice were still alive in all study groups. However, by day 3 , some of the mice were dead with the distribution of dead mice as shown in Table 1

Table 1 shows the results of Chi-square test comparing the proportion of alive mice between the four study groups after 3 days' administration of HSP 70 with three different doses. The results show that the number and proportion of alive mice in i.p. $100 \mu \mathrm{g} / \mathrm{kgBW}$ HSP 70 group (3, $60 \%)$ were higher than the non-HSP 70 group $(2,40 \%)$, but it was statistically non-significant $(\mathrm{OR}=2.25 ; \mathrm{p}=0.527)$. Next, Table 1 shows that the number and proportion of alive mice in i.p. $200 \mu \mathrm{g} / \mathrm{kgBW}$ HSP 70 group $(5,100 \%)$ were higher than the non-HSP 70 group $(2$, $40 \%)$, and it was statistically significant $(\mathrm{OR}=15.40 ; \mathrm{p}=0.038)$. Mice
Table 1: The results of Chi-square test comparing the proportion of alive mice between the four study groups after 3 days' administration of HSP 70 with three different doses

\begin{tabular}{|c|c|c|c|c|c|}
\hline \multirow[t]{3}{*}{ Group by HSP 70 status } & \multicolumn{2}{|c|}{ Outcome } & \multirow{3}{*}{$\begin{array}{l}\text { Total } \\
\text { n (\%) }\end{array}$} & \multirow[t]{3}{*}{ OR } & \multirow[t]{3}{*}{$\mathbf{p}$} \\
\hline & Alive & Death & & & \\
\hline & n (\%) & n (\%) & & & \\
\hline No HSP 70 & $2(40)$ & $3(60)$ & $5(100)$ & 1.00 & 1.00 \\
\hline HSP $70100 \mu \mathrm{g} / \mathrm{kgBW} / \mathrm{ip}$ & $3(60)$ & $2(40)$ & $5(100)$ & 2.25 & 0.527 \\
\hline HSP $70200 \mu \mathrm{g} / \mathrm{kgBW} / \mathrm{ip}$ & $5(100)$ & $0(0)$ & $5(100)$ & 15.40 & 0.038 \\
\hline HSP $70300 \mu \mathrm{g} / \mathrm{kgBW} / \mathrm{ip}$ & $5(100)$ & $0(0)$ & $5(100)$ & 15.40 & 0.038 \\
\hline
\end{tabular}

with i.p. $200 \mu \mathrm{g} / \mathrm{kgBW}$ HSP 70 were 15.40 times more likely to survive than those without HSP 70 of such dose. Finally, Table 1 shows that the number and proportion of alive mice in i.p. $300 \mu \mathrm{g} / \mathrm{kgBW}$ HSP 70 group $(5,100 \%)$ were higher than the non-HSP 70 group (2, 40\%), and it was statistically significant $(O R=15.40 ; p=0.038)$. Mice with i.p. $300 \mu \mathrm{g} / \mathrm{kgBW}$ HSP 70 were 15.40 times more likely to survive than those without HSP 70 of such dose.

Since the incremental HSP 70 dose increase from i.p. $200 \mu \mathrm{g} / \mathrm{kgBW}$ HSP 70 to i.p. $300 \mu \mathrm{g} / \mathrm{kgBW}$ HSP 70 did not result in an increased survival of mice, then it was concluded that the optimal HSP 70 dose to prevent mice mortality was i.p. $200 \mu \mathrm{g} / \mathrm{kgBW}$ HSP 70 .

\section{DISCUSSION}

In this study, the administration of LPS was intended to induce sepsis and eventually MODS in mice under the study. LPS is the main element of Gram-negative bacterial outer membrane [16]. As a study has shown, Gram-negative bacteria cause $30 \%-80 \%$ of sepsis [17]. Sepsis is a complex and serious problem that immediately leads to some states of metabolic change, including MODS, septic shock, and death, respectively [1,2]. The longer MODS is diagnosed, the higher mortality rates, which range from $25 \%$ to $80 \%$ [18].

In multiple organ dysfunction syndrome, the apoptosis process occurs through intrinsic pathway (i.e., mitochondria pathway) $[1,19,20]$. In an apoptosis mitochondria, Bcl-2 homologous antagonist killer (Bak) and BAX molecules constitute the BCL2 pro-apoptosis protein family [21-23]. Activation of homo-oligomerized Bak and BAX has its role in the pore formation of the outer mitochondria membrane. In this process, pro-apoptosis molecules are released, including Smac/Diablo and Cyt c. The Cyt c release leads to an activated caspase. The activated caspase is a sort of protease, which divides the key cellular protein that determines the apoptosis morphology [24]

HSP70 has been widely known to inhibit apoptosis both at the upstream and downstream of mitochondria. For example, a study has shown that $266 \mu \mathrm{g} / \mathrm{kgBW}$ exogenous HSP70 can increase the number of BCL-2 that inhibits apoptosis [7]. In this instance, exogenous HSP70 inhibits apoptosis by preventing the release of Cyt c, Apaf 1 , procaspase 9, and caspase 3 complex. In turn, HSP70 binds Apaf-1, blocks apoptosome, and prevents Caspase 3 activation so that the downstream apoptosis is aborted $[12,14]$.

In theory, HSP70 has its important role both at the upstream and downstream mitochondria along the stress-induced apoptosis pathway by preventing mouse death with an optimal dose of ip $200 \mu \mathrm{g} / \mathrm{kgBW}$ HSP70. In effect, homeostasis becomes balanced, and MODS treatment becomes more rapid and effective with the MODS-induced mortality substantially reduced.

\section{CONCLUSION}

This study gives evidence that the administration of both the ip $200 \mu \mathrm{g} / \mathrm{kgBW}$ HSP70 and $300 \mu \mathrm{g} / \mathrm{kgBW}$ HSP70 were able to make 
mice to survive up to 3 days after intervention. However, the optimal dose to prevent mortality is ip $200 \mu \mathrm{g} / \mathrm{kgBW}$ HSP70. Further studies are suggested to investigate the effect of ip $200 \mu \mathrm{g} / \mathrm{kgBW}$ HSP70 on reducing Cyt $\mathrm{C}$, BAX, and Caspase 3 expressions rather than using ip $266 \mu \mathrm{g} / \mathrm{kgBW}$ HSP 70 dose, to better understand the intermediate pathways that lead to mortality.

\section{AUTHOR'S CONTRIBUTION}

IGL Sukamtogenerated the initial research question, identified coauthors relevant to the study question, carried out some literature review, and wrote the study proposal. Bambang Purwanto discussed and reviewed the biomolecular aspects relevant to address the research question. Ambar Mudigdo reviewed the immunohistochemistry pathological anatomy of Cyt c, BAX, and Caspase 3 expressions. Suroto discussed, reviewed, and critically questioned the sepsis aspects involved in this study. Bhisma Murti designed the overall study including data analysis and writing up the manuscript. Ika Yuli Ayuningrum performed the data analysis, drew tables, wrote, and edited the manuscript of this paper

\section{ACKNOWLEDGMENT}

The authors extend gratitude to PAU, Gadjah Mada University, for permitting to carry out the laboratory study at this laboratory center. The pathology anatomy laboratory at the Faculty of Medicine, Universitas Sebelas Maret, has also facilitated the authors to do the research at this laboratory.

\section{CONFLICTS OF INTEREST STATEMENT}

The authors certify that they have NO affiliations with or involvement in any organization or entity with any financial interest or non-financial interest in the subject matter or materials discussed in this manuscript.

\section{REFERENCES}

1. Guntur HA. Sirs, Sepsis and Syok Septik. Imunologi, Diagnosis Penatalaksanaan. Cetakan 1, Surakarta: UNS Press; 2008. p. 37-48.

2. Singer M. The role of mitochondrial dysfunction in sepsis-induced multi-organ failure. Virulence 2014;5:66-72.

3. Babu M, Menon VP, Devi U. Epidemiology and outcome among severe sepsis and septic shock patients in a South Indian tertiary care hospital. Int J Pharm Pharm Sci 2017:9:256-9.

4. Marshall JC. Multiple organ dysfunction syndrome (MODS). In: Vincent JL, Sibbald WJ, ediotrs. Clinical Trials for the Treatment of Sepsis. Update in Intensive Care and Emergency Medicine. Vol. 19 Berlin, Heidelberg: Springer; 1999

5. Joly AL, Wettstein G, Mignot G, Ghiringhelli F, Garrido C. Dual role of heat shock proteins as regulators of apoptosis and innate immunity. J Innate Immun 2010;2:238-47.
6. Sabirzhanov B, Stoica BA, Hanscom M, Piao CS, Faden AI. Overexpression of HSP70 attenuates caspase-dependent and caspaseindependent pathways and inhibits neuronal apoptosis. J Neurochem 2012;123:542-54.

7. Aschkenasy G, Bromberg Z, Raj N, Deutschman CS, Weiss YG. Enhanced hsp70 expression protects against acute lung injury by modulating apoptotic pathways. PLoS One 2011;6:e26956.

8. Foroutan B, Razavianzadeh N, Anderson D. Overcoming chemoresistance in non-Hodgkin lymphoma preliminary studies of apoptosis and necrosis by P-Glycoprotein reversal agents. Int J Pharm Pharm Sci 2015;7:382-8

9. Masterton RG. Antibiotic de-escalation. Crit Care Clin 2011;27:149-62.

10. Budi S, Ikawati Z, Dwiprahasto I, Nuryastuti T. Antibiotics administration to enhance the success of therapy in sepsis patients. Asian J Pharm Clin Res, Special issue 2017.

11. Santer R. Cellular mechanisms of aging. In: Fillit HM, Rockwood K, Woodhouse K, edtiors. Brocklehurst's Textbook of Geriatric Medicine and Gerontology. $7^{\text {th }}$ ed. Philadelphia, PA: Saunders/Elsevier; 2010.

12. Choudhury S, Bae S, Ke Q, Lee JY, Kim J, Kang PM, et al. Mitochondria to nucleus translocation of AIF in mice lacking hsp70 during ischemia/ reperfusion. Basic Res Cardiol 2011;106:397-407.

13. Kustanova GA, Murashev AN, Karpov VL, Margulis BA, Guzhova IV, Prokhorenko IR, et al. Exogenous heat shock protein 70 mediates sepsis manifestations and decreases the mortality rate in rats. Cell Stress Chaperones 2006;11:276-86.

14. Evans CG, Chang L, Gestwicki JE. Heat shock protein 70 (hsp70) as an emerging drug target. J Med Chem 2010;53:4585-602.

15. Lee HJ, Ock CY, Kim SJ, Hahm KB. Heat shock protein: Hard worker or bad offender for gastric diseases. Int J Proteomics 2010;2010:11.

16. Green DR. Means to an End: Apoptosis and Other Cell Death Mechanisms. Cold Spring Harbor Laboratory Press. 2011. ISBN: 9780-879698-87-4.

17. Kalogeris T, Baines CP, Krenz M, Korthuis RJ. Cell biology of ischemia/reperfusion injury. Int Rev Cell Mol Biol 2012;298:229-317.

18. Martinvalet D, Zhu P, Lieberman J. Granzyme A induces caspaseindependent mitochondrial damage, a required first step for apoptosis. Immunity 2005;22:355-70.

19. Elmore S. Apoptosis: A review of programmed cell death. Toxicol Pathol 2007;35:495-516.

20. Van Amersfoort ES, Van Berkel TJ, Kuiper J. Receptors, mediators, and mechanisms involved in bacterial sepsis and septic shock. Clin Microbiol Rev 2003;16:379-414.

21. Galley HF. Bench-to-bedside review: Targeting antioxidants to mitochondria in sepsis. Crit Care 2010;14:230.

22. Xu JT, Vanderlick K, Beales PA. Lytic and non-lytic permeabilization of kardiolipin-containing lipid bilayers induced by cytochrome c. PLoS One 2013;8:e69492

23. Brunelle JK, Letai A. Control of mitochondrial apoptosis by the bcl-2 family. J Cell Sci 2009;122:437-41

24. Jiang $X$, Jiang $H$, Shen $Z$, Wang $X$. Activation of mitochondrial protease OMA1 by bax and bak promotes cytochrome c release during apoptosis. Proc Natl Acad Sci U S A 2014;111:14782-7. 